\title{
Peta Digital Demografi Penduduk Tingkat Desa Berbasis Web Menggunakan Google Maps API
}

\author{
Fajri Profesio Putra ${ }^{1}$ Danuri $^{2}$ \\ 1,2Program Studi Rekayasa Perangkat Lunak Jurusan Teknik Informatika \\ 1,2Politeknik Negeri Bengkalis \\ Jl. Bathin Alam, Sei. Alam, Bengkalis, Riau, Telp. (0766) 24566 \\ e-mail: ${ }^{1}$ fajri@ polbeng.ac.id, ${ }^{2}$ danuri@ polbeng.ac.id ${ }^{\mathrm{s}}$
}

\begin{abstract}
Abstrak
Pemetaan demografi berbasis digital saat ini diperlukan dalam memudahkan masyarakat khususnya pejabat daerah dalam mengetahui sebaran populasi suatu wilayah. Peta demografi juga dapat menyajikan data statistik tentang tingkat pendidikan suatu wilayah, pekerjaan, usia, dan tanggungan keluarga. Saat ini untuk informasi demografi pada wilayah pemerintahan tingkat desa Kabupaten Bengkalis masih didata secara manual, sehingga untuk memperoleh informasi masyarakat harus mengakses data atau melihat data dikantor desa. Penelitian sistem demografi penduduk tingkat desa ini merupakan aplikasi berbasis web dimana untuk peta wilayah desa dintegrasikan dengan memanfaatkan fasilitas Google Maps API. Pada sistem ditampilkan peta desa serta batas-batas wilayah untuk tingkat rt/rw dengan menentukan batas longitude dan latitude. Selanjutnya disediakan menu untuk administrator agar dapat menginputkan data-data kependudukan untuk selanjutnya ditampilkan dalam bentuk grafik. Adanya sistem ini dapat menghasilkan informasi yang berkualitas, terkini serta berguna untuk pengambil keputusan dalam menentukan kebijakan terhadap penduduk. Hal ini juga membantu pemerintah dalam membangun semangat untuk keterbukaan informasi.
\end{abstract}

Kata Kunci: peta, demografi,,kependudukan, statistik, desa

\begin{abstract}
Digital-based demographic mapping is currently required to facilitate the community, especially local officials in knowing the distribution of a region's population. Demographic maps can also provide statistical data about the educational level of a region, occupation, age, and family dependents. Currently for demographic information at the village level government of Bengkalis Regency is still recorded manually, so to obtain information the community must access data or view data at the village office. This village population demography system research is a web-based application where the village area map is integrated by utilizing the Google Maps API facility. In the system is shown the map of the village as well as the boundaries of the region for $r$ t/rw level by determining the limits of longitude and latitude. Further provided the menu for administrators to be able to input demography data and will be displayed in graphical form. The existence of this system can produce quality information, current and useful for decision makers in determining the policy against the population. It also helps the government in building a passion for information disclosure.
\end{abstract}

Keyword: map, demographic, population, statistic, village

\section{Pendahuluan}

Kemajuan informasi mengambil peranan dalam kemajuan teknologi, kemajuan ini menawarkan berbagai kemudahan dalam mencari dan menyebarluaskan sebuah informasi. Salah satu sarana yang dapat digunakan adalah dengan memanfaatkan teknologi jaringan internet [1]. Penyajian informasi secara digital pada saat ini diperlukan dalam membantu masyarakat dan khususnya pemangku kepentingan dalam memperoleh informasi dan membuat kebijakan. Salah 
satunya adalah informasi tentang kependudukan dan pemetaan sebuah wilayah. Data dapat disajikan dalam bentuk aplikasi berbasis web dimana aplikasi tersebut dapat diakses dimanapun selama masih terkoneksi pada jaringan internet.

Demografi adalah ilmu yang mempelajari jumlah persebaran, teritorial dan komposisi penduduk serta perubahan-perubahannya dan sebab dari perubahan tersebut. Adanya pengetahuan tentang kependudukan penting untuk lembaga-lembaga swasta maupun pemerintahan baik di tingkat nasional maupun daerah. Hal ini sebagai acuan untuk perencanaan program tentang pendidikan, perpajakan,dan perusahaan-perusahaan yang memproduksi barang dan jasa, jalan, rumah-rumah sakit, pusat-pusat pertokoan dan pusat-pusat rekreasi akan menjadi lebih tepat apabila kesemuanya di dasarkan pada data kependudukan [2]

Sistem informasi geografis merupakan suatu sistem informasi khusus mengelola data yang memiliki informasi spasial [3]. Informasi geografis yang terdapat dalam sistem informasi geografis dapat berupa informasi wilayah administasi suatu daerah, sebaran penduduk, sebaran kasus penyakit, dan sebagainya. Informasi-informasi yang disajikan melalui peta tersebut merupakan informasi yang sangat penting terutama dalam penyajian data spasial, agar mudah dipahami dan dianalisis oleh pihak lain. Sistem informasi geografis (SIG) merupakan salah satu tools yang dapat membantu menganalisa kondisi suatu daerah terhadap informasi penduduk dan sebaran wilayah. Adanya SIG dapat membantu untuk meanmpilkan informasi pada satu wilayah di tingkat desa dan divisualisasikan dalam bentuk peta digital.

Penelitian pemanfaatan SIG telah dilakukan diantaranya yaitu pemetaan penderita gizi buruk di Kota Pekanbaru menggunakan Quantum QIS untuk membantu Dinas Kesehatan Kota Pekanbaru dalam memantau jumlah penderita gizi buruk berdasarkan wilayah geografis, kelompok umurdan periode waktu. Aplikasi yang dihasilkan dapat menyajikan informasi geografis penderitagizi buruk anak usia 0-5 tahun di kota Pekanbaru berdasarkan wilayah kecamatan [4]. Pada Google terdapat layanan aplikasi peta berbasis web yaitu Google Maps. Aplikasi ini menyediakan layanan untuk menambahkan fitur peta digital pada sebuah halaman web secara gratis dengan untuk pemakaian non-komersial [5]. Layanan Google Maps API menggunakan perpaduan antara fungsi html dan javascript [6].

Salah satu pemanfaatan layanan Google Maps adalah untuk manajemen bantuan logistik pasca bencana alam berbasis mobile web yang dapat memberikan informasi jarak rute jalan,penunjuk arah jalan, dan informasi tentang lokasi posko bencana alam. Sistem ini sangat membantu pengguna untuk mengurangi penumpukan bantuan logistic dan meningkatkan efektifitas pemberian bantuan yang tepat sasaran [7]. Selanjutnya pemanfaatan fitur google maps untuk pemantauan traffic lalu lintas diwilayah DKI Jakarta [8], pada penelitian ini dikembangkan prototipe yang dapat menyediakan informasi tentang kondisi jalan seperti titik rawan kemacetan, penyebab kemacetan, keterangan jalan yang dilintasi, maupun informasi lain seperti bencana, kerusakan, keramaian di wilayah DKI Jakarta.

Beberapa daerah di Indonesia proses pendataan penduduk masih menggunakan sistem manual yang menyebabkan kurangnya validitas dan ketidaksesuaian data, sehingga data-data yang dihasilkan kurang lengkap, benar dan tepat [9]. Sistem pendataan kependudukan dibeberapa wilayah khususnya daerah kabupaten Bengkalis masih dilakukan secara manual, menyebabkan pendataan penyebaran penduduk dan pengembangan SDM pada suatu daerah khususnya di suatu desa sulit untuk diakses secara cepat dan perubahan data tidak dilakukan secara cepat. Untuk itu perlu adanya sebuah aplikasi yang memuat informasi kependudukan dilengkapi peta digital demografi berbasis web [10]. Dimana aplikasi ini dapat menampilkan pemetaan wilayah desa dan statistik penduduk dalam usia produktif disuatu wilayah desa. Informasi yang diberikan terkait kondisi penduduk dari tingkat pendidikan, mata pencarian dan tingkat usia produktif disuatu RT dan RW.

Tujuan dari penelitian ini menghasilkan sebuah aplikasi berbasis SIG yang menampilkan data wilayah tingkat RT pada sebuah desa dimana pada aplikasi juga disajikan data penduduk dalam bentuk data statistik yang dikategorikan berdasarkan usia, pendidikan, pekerjaan dan 
tanggungan seorang kepala keluarga. Data statistic ini disajikan untuk setiap RT. Implementasi SIG memanfaatkan layanan Google Maps untuk membuat titik polygon sebagai batasan wilayah pada setiap RT di sebuah desa. Diharapkan dengan adanya aplikasi ini dapat membantu masyarakat untuk mendapat kan informasi statistik kependudukan.

\section{Metode Penelitian}

2.1 Sumber Data

Sebagai bahan acuan yang digunakan untuk Peta Digital Demografi Penduduk Tingkat Desa Berbasis Web adalah salah satu data desa yang terdapat di Kabupaten Bengkalis, Riau yaitu desa Wonosari. Fitur peta pada halaman web dapat ditambahkan dengan memanfaatkan Google Maps API dimana merupakan sebuah library java script, dengan Google Maps API memungkin kita untuk melakukan kostumasi tampilan peta dengan menambahkan warna, informasi dan penambahan marker pada aplikasi peta yang dibuat.. Untuk dapat menggunakan Google Maps API harus terkoneksi kejaringan internet.

2.2 Tahapan pembuatan sistem

Supaya proses penelitian lebih terarah maka dilakukan beberapa prosedur secara terurut dan sistematis dimulai dari mengidentifikasi masalah sampai hasil dan pengujian aplikasi. Prosedur penelitian dapat dilihat pada Gambar 1.

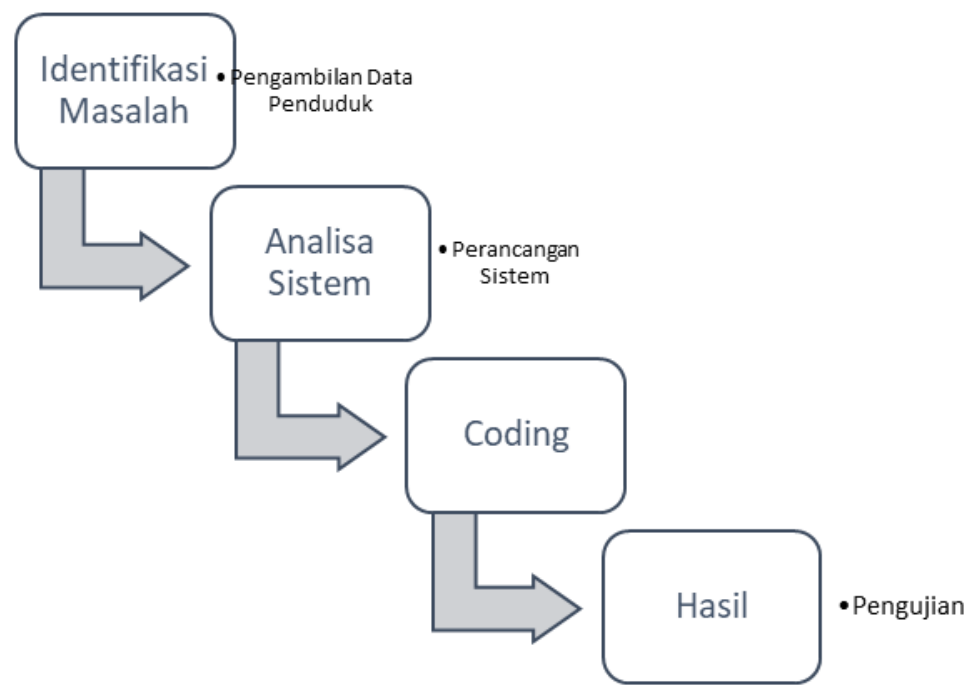

Gambar 1. Rancangan Pembuatan Sistem

Uraian yang dilaksanakan pada setiap tahapan adalah sebagai berikut:

a. Identifikasi Masalah

Tahap ini dilaksanakan dengan mengumpulkan semua data yang terkait dalam pembuatan sistem. Pada tahap ini data dan informasi yang dikumpulkan adalah informasi terhadap batas wilayah dengan mengambil titik longitude dan latitude menggunakan GPS. Data penduduk terkait usia, pekerjaan, jumlah tanggungan dan pendidikan. Data telah diperoleh dianalisa terlebih dahulu untuk mendapatkan input dan output yang akan dihasilkan.

b. Analisa Sistem

Pada tahap Analisa dilakukan perancangan sistem menggunakan tool UML, dimulai dari pembuatan use case, sequence diagram, acitivity diagram, class diagram. Proses perancangan menggunakan UML untuk memperjelas fungsi masing-masing actor. Perancangan menggunakan UML juga diikuti dengan perancangan interface dan ERD database. 
c. Coding

Setelah perancangan dengan menggunakan UML selanjutnya dilakukan tahap pengkodean dimana pembuatan sistem ini menggunakan Bahasa pemograman PHP dan database MySQL dan untuk pembuatan peta menggunakan Google Maps API.

d. Hasil

Pada tahap ini dilakukan pengujian seluruh fungsionalitas aplikaksi. Pendekatan yang dilakukan dengan metode black box dengan tujuan untuk menjamin sistem yang dibuat sesuai dengan hasil analisis dan perancangan

\section{Hasil dan Pembahasan}

\subsection{Proses Pembuatan Digital}

Untuk proses pemetaan system menggunakan fasilitas dari Google Maps dengan memanfaatkan fungsi Application Programming Interface (API) dari Google Map. Untuk implementasi data data pada wilayah Desa Senggoro, Kabupaten Bengkalis. WEBGIS KEPENDUDUKAN

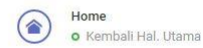

(ii) 74
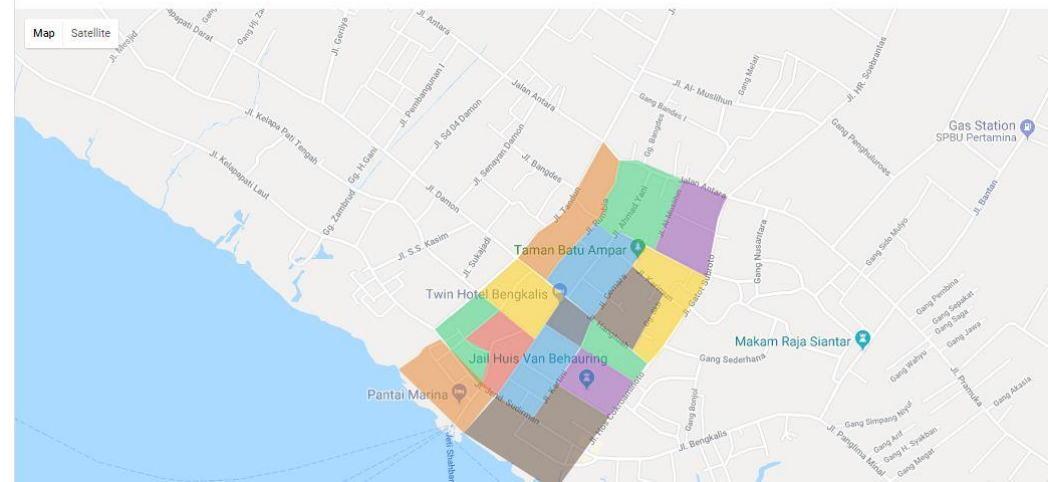

Gambar 2. Peta Digital Untuk Kependudukan Wilayah Desa Senggoro Kab. Bengkalis

Untuk menandai batas wilayah menggunakan titik polygon dimana setiap wilayah yang dibedakan dengan warna yang berbeda. Pada gambar 2, untuk satu wilayah desa terdapat 15 RT. Setiap wilayah RT akan memuat informasi tentang nama dan no kontak dari Ketua RT seperti yang ditampilkan pada gambar 3. Untuk mengetahui siapa penduduk yang menempati wilayahnya maka dapat membuka link Data Lengkap.

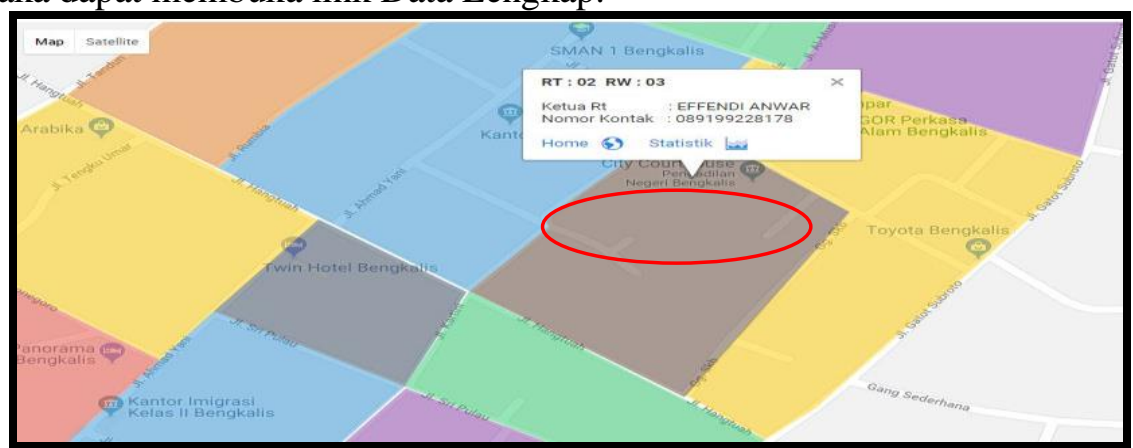

Gambar 1. Detail Info Kependudukan Tingkat RT

\subsection{Pembuatan Antarmuka Pengguna}


Berikut adalah halaman antar muka pada aplikasi Peta Digital Demografi Penduduk Tingkat Desa Berbasis Web Menggunakan Google Maps API.

a. Tampilan halaman utama

Tampilan halaman utama pada gambar 4, menampilkan peta untuk wilayah Pulau Bengkalis dimana terdapat satu wilayah desa yang sudah dibatasi dengan menggunakan titik polygon.

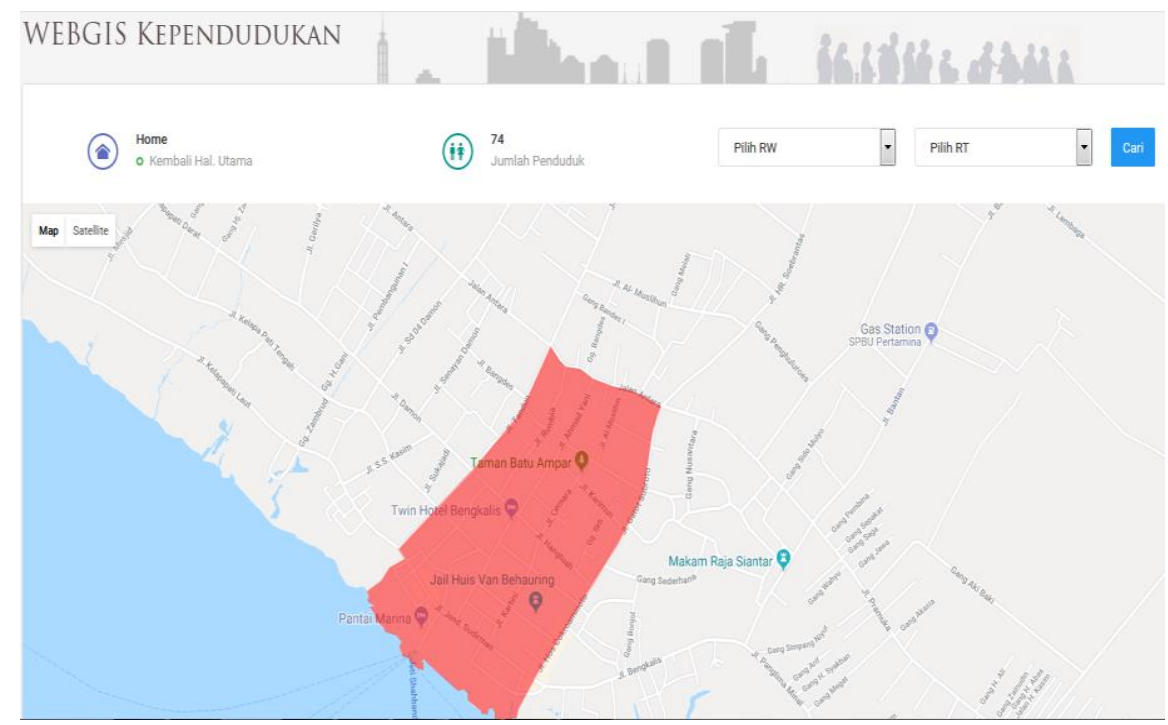

Gambar 4. Halaman Utama Aplikasi

b. Tampilan halaman input data

Pada halaman ini hanya dapat diakses oleh actor/user admin dimana user harus login ke halaman admin. Dihalaman admin terdapat dua Form utama yaitu halaman untuk input data kelurahan/desa dan input data penduduk. Gambar 5. tampilan untuk halaman admin.

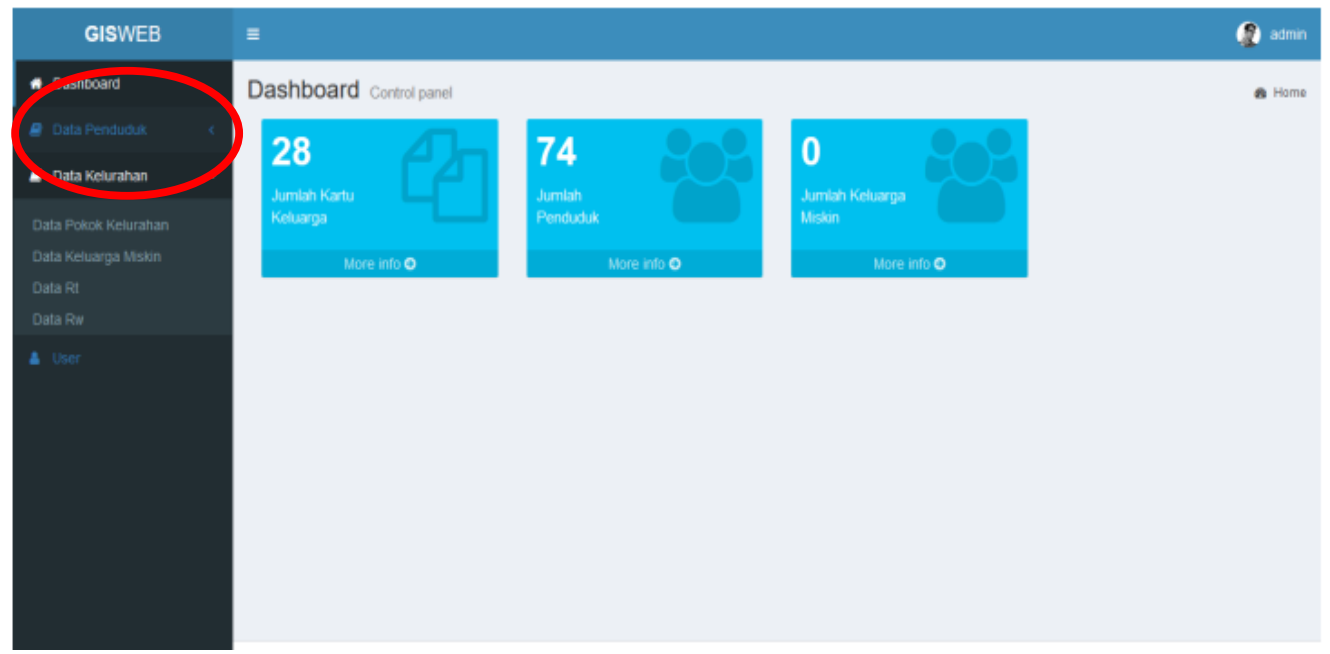

Gambar 5. Tampilan Halaman Admin

Selanjutnya pada halaman input data kelurahan. User admin dapat menmbahakan data tentang wilayah Desa dan informasi wilayah untuk setiap RT. Gambar 6, menampilkan form 
inputan untuk memasukkan informasi wilayah tingkat RT. Pada halaman ini dimasukkan titik polygon untuk batas wilayah desa.

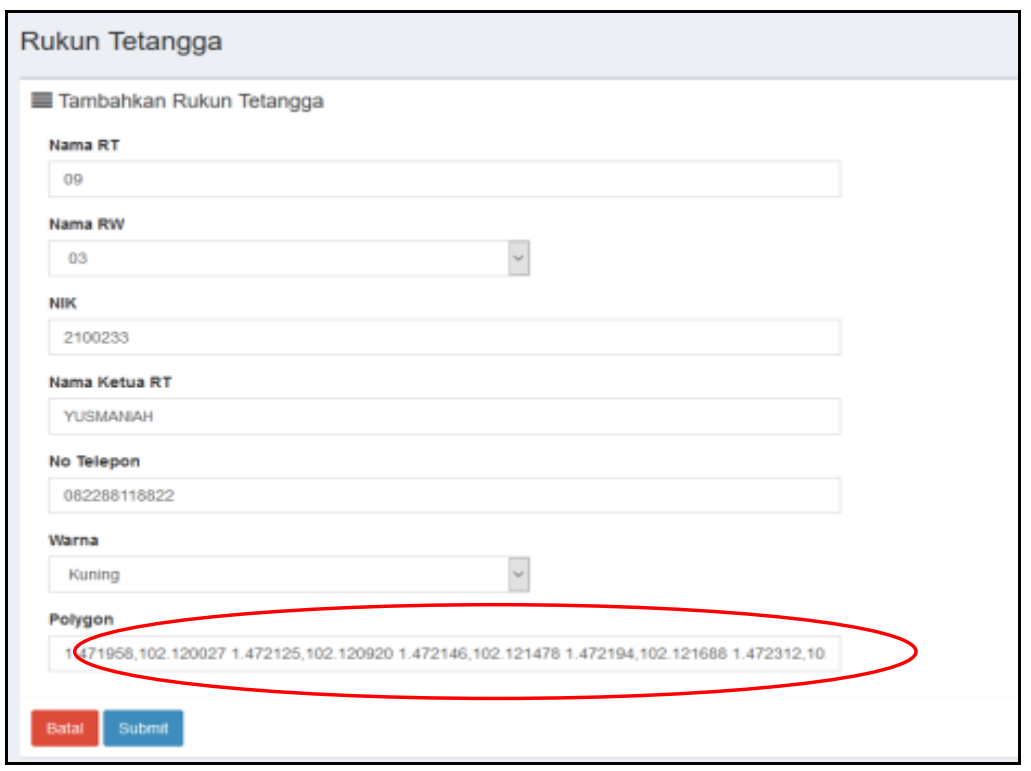

Gambar 6. Halaman input info wilayah RT

c. Halaman input data penduduk

Untuk inputan data penduduk dapat dilihat pada Gambar 7. Pada form ini disediakan untuk input data pada setiap KK.

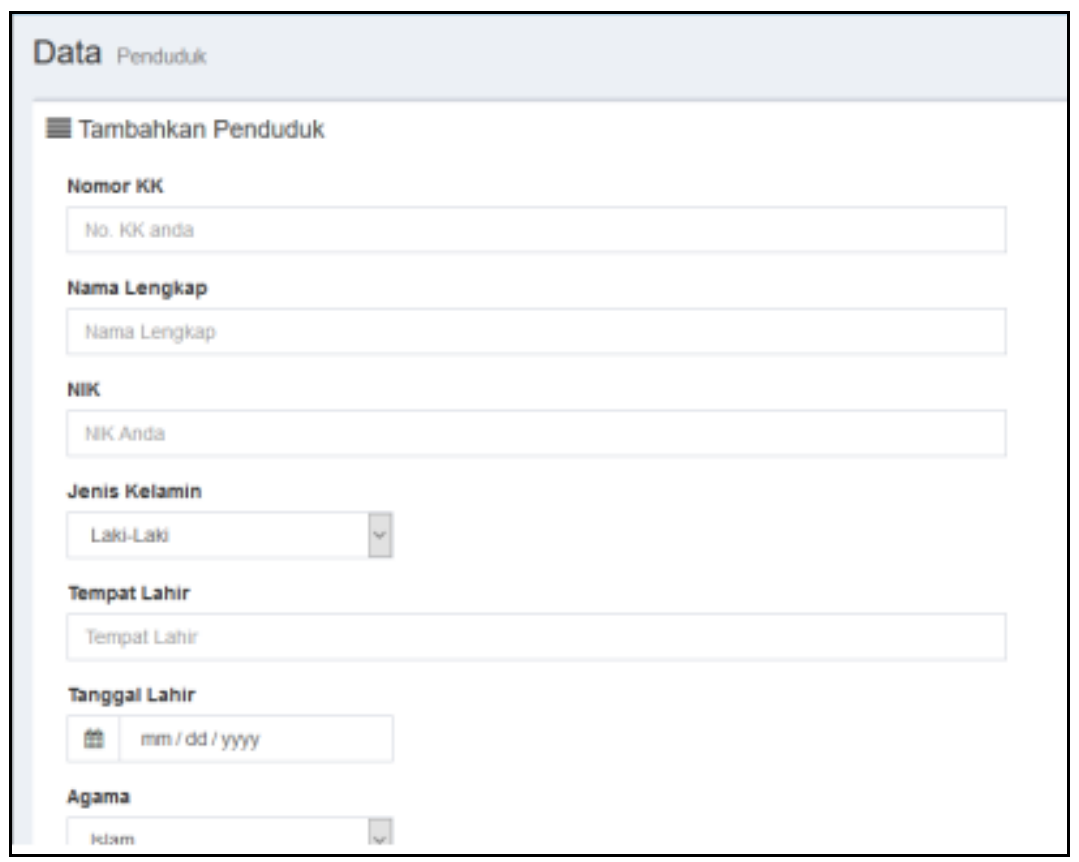

Gambar 7. Form input data penduduk setiap KK

d. Halaman statis penduduk 
Untuk setiap wilayah RT akan ditunjukkan statistik dari setiap penduduk diwilayah RT dengan pengelompokan data berdasarkan Jenis Kelamin, Usia, Pendidikan Pekerjaan dan Penghasilan seperti terlihat pada gambar 8 .

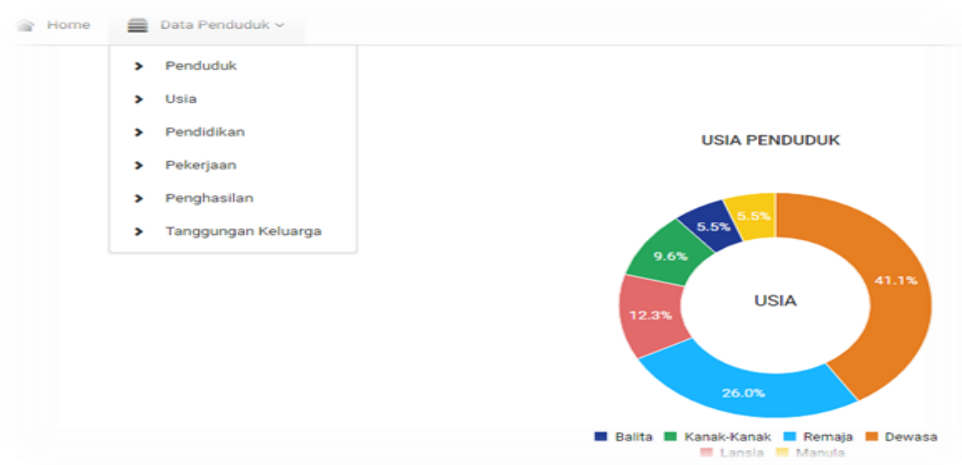

Gambar 8. Tampilan Grafik Statistik Kependudukan (USIA)

\subsection{Pengujian}

Teknik pengujian peta digital demografi penduduk tingkat desa berbasis web menggunakan teknik pengujian blackbox. Pengujian menggunakan teknik black box betujuan untuk melihat masukan dan keluaran, apakah berjalan sesuai dengan rancangan dan diproses secara cepat. Pada pengujian black box dilakukan identifikasi untuk kesalahan pada fungsionalitas perangkat lunak berdasarkan kesalahan pada output.

a. Rencana Pengujian

Pengujian peta digital demografi penduduk tingkat desa berbasis web ini menggunakan data uji berupa login sistem, proses input data, pengujian peta dan grafik penduduk seperti tertuang pada tabel 1 .

Tabel 1. Rencana pengujian

\begin{tabular}{|l|l|l|}
\hline \multicolumn{1}{|c|}{ Kelas uji } & \multicolumn{1}{c|}{ Butir uji } & Jenis pengujian \\
\hline Login & Pengecekan username yang sudah ada & Black box \\
\hline Input data & $\begin{array}{l}\text { Input data penduduk, data desa, data rt } \\
\text { dan polygon wilayah }\end{array}$ & Black box \\
\hline Pengujian peta & Melihat output hasil polygon wilayah & Black box \\
\hline Grafik penduduk & Melihat grafik kependudukan & Black box \\
\hline
\end{tabular}

b. Kasus dan Hasil pengujian

Kasus dan Hasil pengujian terdiri dari pengujian login, pengujian menu pengguna, dan pengujian lihat peta . Pada tabel 2 ditampilkan hasil pengujian untuk menu login menggunakan data benar dan salah.

Tabel 2. Pengujian login admin sistem (backend user)

\begin{tabular}{|l|l|l|l|}
\hline \multicolumn{4}{|c|}{ Kasus dan Hasil Uji (data normal) } \\
\hline \multicolumn{1}{|c|}{ Data } & \multicolumn{1}{|c|}{ Output } & Pengamatan & Pengamatan \\
\hline $\begin{array}{l}\text { Username: admin } \\
\text { Password: admin1020 }\end{array}$ & $\begin{array}{l}\text { Tampil halaman } \\
\text { admin }\end{array}$ & $\begin{array}{l}\text { Halaman admin } \\
\text { tampil }\end{array}$ & Diterima \\
\hline \multicolumn{4}{|c|}{ Kasus dan Hasil Uji (data salah) } \\
\hline $\begin{array}{l}\text { Username: fajri } \\
\text { Password: fajri1020 }\end{array}$ & Tampil peringatan & $\begin{array}{l}\text { Pesan peringatan } \\
\text { tampil }\end{array}$ & Diterima \\
\hline
\end{tabular}

Selanjutnya pengujian untuk input data dihalaman admin dilakukan pada menu data desa dan penduduk. Hasil pengujian menggunakan data normal dan data salah disajikan pada tabel 3 dan 4. 
Tabel 3. Tabel pengujian menu data RT

\begin{tabular}{|c|c|c|c|}
\hline \multicolumn{4}{|c|}{ Kasus dan Hasil Uji (data normal) } \\
\hline Data & Output & Pengamatan & Pengamatan \\
\hline $\begin{array}{l}\text { Tambah nama } \\
\text { desa dan polygon } \\
\text { batas wilayah }\end{array}$ & $\begin{array}{l}\text { Data baru masuk } \\
\text { kedalam database }\end{array}$ & $\begin{array}{l}\text { Data desa masuk } \\
\text { kedalam database }\end{array}$ & Diterima \\
\hline $\begin{array}{l}\text { Ubah nama desa } \\
\text { dan polygon } \\
\text { batas wilayah } \\
\text { desa yang sudah } \\
\text { ada }\end{array}$ & $\begin{array}{l}\text { Data lama diganti data } \\
\text { baru didalam database }\end{array}$ & $\begin{array}{l}\text { Data desa yang } \\
\text { diunputkan di update }\end{array}$ & Diterima \\
\hline $\begin{array}{l}\text { Hapus data desa } \\
\text { dan polygon } \\
\text { batas wilayah }\end{array}$ & $\begin{array}{l}\text { Data desa dihapus } \\
\text { dalam database }\end{array}$ & $\begin{array}{l}\text { Data desa terhapus } \\
\text { dari database }\end{array}$ & Diterima \\
\hline \multicolumn{4}{|c|}{ Kasus dan Hasil Uji (data salah) } \\
\hline $\begin{array}{l}\text { Input nama desa } \\
\text { yang sudah ada } \\
\text { pada data desa }\end{array}$ & Tampil peringatan & $\begin{array}{l}\text { Pesan peringatan } \\
\text { tampil }\end{array}$ & Diterima \\
\hline
\end{tabular}

Tabel 4. Tabel pengujian menu data penduduk

\begin{tabular}{|c|c|c|c|}
\hline \multicolumn{4}{|c|}{ Kasus dan Hasil Uji (data normal) } \\
\hline Data & Output & Pengamatan & Pengamatan \\
\hline $\begin{array}{lr}\text { Tambah } & \text { data } \\
\text { penduduk dengan } \\
\text { inputkan } & \text { NIK } \\
\text { dan } & \text { KK } \\
\text { penduduk } & \end{array}$ & $\begin{array}{l}\text { Data baru masuk } \\
\text { kedalam database }\end{array}$ & $\begin{array}{l}\text { Data desa masuk } \\
\text { kedalam database }\end{array}$ & Diterima \\
\hline $\begin{array}{ll}\text { Ubah } & \text { NIK } \\
\text { penduduk } & \end{array}$ & $\begin{array}{l}\text { Data lama diganti data } \\
\text { baru didalam database }\end{array}$ & $\begin{array}{l}\text { Data desa yang } \\
\text { diunputkan di update }\end{array}$ & Diterima \\
\hline $\begin{array}{l}\text { Hapus satu data } \\
\text { penduduk }\end{array}$ & $\begin{array}{l}\text { Data desa dihapus } \\
\text { dalam database }\end{array}$ & $\begin{array}{l}\text { Data desa terhapus } \\
\text { dari database }\end{array}$ & Diterima \\
\hline \multicolumn{4}{|c|}{ Kasus dan Hasil Uji (data salah) } \\
\hline $\begin{array}{l}\text { Tambah data } \\
\text { NIK penduduk } \\
\text { yang sudah ada }\end{array}$ & Tampil peringatan & $\begin{array}{l}\text { Pesan peringatan } \\
\text { tampil }\end{array}$ & Diterima \\
\hline
\end{tabular}

Pada pengujian peta digital dilakukan pengujian pada saat aplikasi digunakan ketika offline dan online seperti yang ditampilkan pada tabel 5 .

Tabel 5. Pengujian terhadap halaman peta

\begin{tabular}{|c|c|c|c|}
\hline \multicolumn{4}{|c|}{ Kasus dan Hasil Uji (data normal) } \\
\hline Data & Output & Pengamatan & Pengamatan \\
\hline $\begin{array}{l}\text { Halam utama } \\
\text { memperlihatkan peta pada } \\
\text { saat Online }\end{array}$ & $\begin{array}{l}\text { Munculnya peta } \\
\text { google maps dan } \\
\text { peta pulau } \\
\text { bengkalis }\end{array}$ & $\begin{array}{l}\text { peta google maps } \\
\text { dan peta pulau } \\
\text { bengkalis muncul } \\
\text { dihalaman utama }\end{array}$ & Diterima \\
\hline \multicolumn{4}{|c|}{ Kasus dan Hasil Uji (data salah) } \\
\hline $\begin{array}{l}\text { Halam utama } \\
\text { memperlihatkan peta pada } \\
\text { saat Offline }\end{array}$ & $\begin{array}{l}\text { Peta google maps } \\
\text { dan peta pulau } \\
\text { bengkalis tidak } \\
\text { muncul }\end{array}$ & $\begin{array}{l}\text { peta google maps } \\
\text { tidak muncul }\end{array}$ & Diterima \\
\hline
\end{tabular}


c. Kesimpulan pengujian

Berdasarkan pengujian menggunakan metode Blackbox maka diperoleh kesimpulan sebagai berikut:

1) Antar muka sistem yang dibangun cukup baik dan mudah digunakan.

2) Fungsi-fungsi yang dirancang dapat dijalankan dengan benar.

3) Menampilkan pesan peringatan jika data tidak sesuai dengan database.

4) Menampilkan pesan peringatan jika data sudah ada didalam database (data sama).

5) Peta digital tidak akan tampil jika aplikasi digunakan dalam kondisi tidak terhubung ke jaringan internet.

\section{Kesimpulan}

Hasil dari penelitian ini adalah Peta Digital Demografi Penduduk Tingkat Desa Berbasis Web Menggunakan Google Maps API yang dapat membantu masyarakat dan khususnya Pemerintah Desa atau Kota dalam memberikan infomasi peta wilayah dan kependudukan berdasarkan tingkat pendidikan, usia, penghasilan dan pekerjaan serta tanggungan keluarga berdasarkan wilayah tingakat desa maupun RT. Untuk peta wilayah disajikan dalam bentuk peta wilayah dimana setiap batas wilayah akan dibedakan dengan menggunakan batas polygon dan warna yang berbeda setiap wilayah. Untuk informasi kependudukan data disajikan dalam bentuk grafik lingkaran dan dapat dipilih berdasarkan kelompok usia, pendidikan, dan pekerjaan.

\section{Daftar Pustaka}

[1] Suhada, Khairus, Danuri, dan Putra, Fajri P., Aplikasi web promosi kuliner dan rumah makan online, Jurnal Teknologi Informasi \& Komunikasi Digital Zone. 2017. Vol $8(1): 25-33$

[2] Syaadah, Nilatus. Analisis Dampak Pertambahan Penduduk Terhadap Penyerapan Angkatan Kerja, Jurnal Ilmiah Pendidikan Geografi. 2017. Vol2(1):61-70

[3] Nur Rizky, YR, Aplikasi Sistem Informasi Geografis Berbasis WEB untuk Persebaran Sekolah Menengah Atas, Jurnal Geodesi Undip , 2015;4(1);173

[4] Fitri, Triyani A. dan Ferdiansyah, Rio. Aplikasi Pemetaan Penderita Gizi Buruk di Kota Pekanbaru menggunakan Quantum GIS. Jurnal Teknologi Informasi \& Komunikasi Digital Zone. 2017. Vol 8(2):125-136

[5] Pramartha, I. M. A. Implementasi Aplikasi SIG Dalam Pengolahan Data Jumlah Penduduk Berbasis Web. Jurnal Elektronik Ilmu Komputer, 2012;1(2); 87-91

[6] Yuhana, Umi L., Cahyadi, Oka, Fabroyir, Hadziq Pemanfaatan Googlemaps Untuk Pemetaan dan Pencarian Data Perguruan Tinggi Negeri Di Indonesia. 2010. Jurnal Sistem Informasi hal 21-26

[7] Mahdia, Faya dan Noviyanto, Fiftin. Pemanfaatan Google Maps Api Untuk Pembangunan Sistem Informasi Manajemen Bantuan Logistik Pasca Bencana Alam Berbasis. Mobile Web, Jurnal Sarjana Teknik Informatika 2013. Vol1(1):162-171

[8] Utari, Retno Dyah. Wibowo, Arief. Pemanfaatan Google Maps dalam Pembuatan Aplikasi Pemantau Kondisi Jalan dan Lalu lintas. 2013. Prosiding. Seminar Nasional Teknologi Informasi dan Komunikasi ISBN 978-602-19837-2-0

[9] Setiadi, M., D., Piarsa, I., dan N., Mandenni, N., M., M., 2015 Sistem Informasi Georafis Pemetaan Tingkat Pertumbuhan Penduduk Berbasis Web, Merpati, Vol. 3, No.3, 22523006

[10] Putra, Fajri P., dan Danuri. Rancangan Bangun Peta Demografi Kependudukan Berbasis Web. Prosiding, Seminar Nasional Industry dan Teknologi 2017. Bengkalis 